\title{
DAYUNG BORIH, THE CONDUITS OF THE BIDAYUH AND THE SPIRITUAL WORLD
}

\author{
Yvonne Michelle Campbell* \& Damien Anak Mikeng \\ ${ }^{*}$ First author \\ Faculty of Language and Communication \\ Universiti Malaysia Sarawak \\ Sarawak, Malaysia \\ (mvyvonne@unimas.my; mdamien@unimas.my) \\ DOI: https://doi.org/10.22452/brj.vol13no1.6
}

\begin{abstract}
Dayung Borih, or Bidayuh priestess and Gawai are two important cultural elements within the context of the traditional Bidayuh of Sarawak. This paper examines the role and significance of Gawai and Dayung Borih within the Bidayuh community. The data for this study was collected through a series of interviews and participant observations conducted in two villages in the Bau district. The interviews revealed that the concept of Gawai in the olden days was a form of rituals relating human to spiritual beings with the help of the Dayung Borih acting as mediators. The role of Dayung Borih was not only limited to mediators but also healers whereby they performed healing Gawai. The traditional Bidayuh believed that these Dayung Borih were gifted women selected by the spirits themselves. It was a highly respected position within the Bidayuh community but physically, mentally and spiritually demanding for these women. However, the number of Dayung Borih is decreasing and together with it their significant in the community as well as the concept of Gawai, which has changed due to modernisation within the Bidayuh community.
\end{abstract}

Keywords: Bidayuh, priestess, ritual, spirits, communication

\section{Introduction}

The Bidayuh is one of the many ethnic groups residing in the Malaysian Borneo state of Sarawak. They belong to the Austronesia - Malayo-Polynesian group, which share similarities in terms of culture and language with the indigenous groups of Indonesia, the Philippines and Madagascar. According to Chang (2002, 2004), the Bidayuh in Sarawak originated from West Kalimantan, Indonesia. The 
Bidayuh makes up $8 \%$ of the total population of Sarawak with 335 villages within the Kuching and Serian Divisions (Chang, 2002, 2004).

According to Bongarra, Kayad and Campbell (2017), the Bidayuh could be divided into six main groups based on their dialectal similarities which are the Biatah, Bau-Jagoi, Bukar-Sadong, Tringgus/Sembaan, Salako and Rara. Table 1 and Figure 1 below present these dialectal groups and their geographical locations:

Table 1: Bidayuh languages in Sarawak

\begin{tabular}{|l|l|l|}
\hline District & Bidayuh groups & Dialects \\
\hline $\begin{array}{l}\text { Kuching (Penrissen } \\
\text { and Padawan) }\end{array}$ & Biatah & $\begin{array}{l}\text { Biatah, Bibenuk, Bipuruh, Bistaang, } \\
\text { Bisapug, Pinyawa', Biya etc... }\end{array}$ \\
\hline Bau & Bau-Jagoi & Jagoi, Singai, Serembu, Bratak, Gumbang \\
\hline Serian & Bukar-Sadong & $\begin{array}{l}\text { Bukar, Sadung, Tebakang, Sadung Bunan, } \\
\text { Sangking, Mentu Tapuh }\end{array}$ \\
\hline $\begin{array}{l}\text { Bau, Penrissen, } \\
\text { Padawan }\end{array}$ & $\begin{array}{l}\text { Tringgus/ } \\
\text { Sembaan }\end{array}$ & Sembaan, Tringgus Raya, Trunggus Bireng \\
\hline Lundu & Salako & Salako \\
\hline Lundu & Rara & Lara, Rara-Bakati' \\
\hline
\end{tabular}

Source: Bongarra, Kayad and Campbell (2017, p. 217).

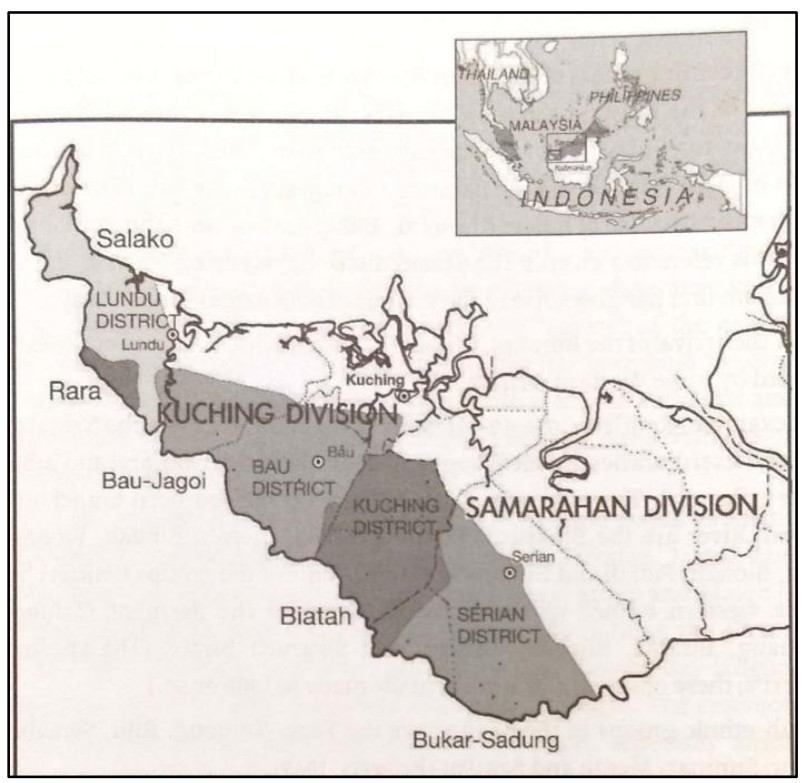

Figure 1: Major dialect groupings of Bidayuh

(Source: Noeb and Ridu [2017, p. 5].) 
One of the Bidayuh groups, which is the Bau-Jagoi group, resides mainly in the Bau district, focusing mainly around Bung Jagoi or Mount Jagoi. Traditionally, the Bidayuh lived in a longhouse which consists of about 20 individual houses of families living together in one stretch of a longhouse (Nuek, 2002). The Bidayuh call their longhouse botang romin, which literally means 'tree trunk house' made of ironwood as the main frame, sago leaves for the roof and a type of bamboo, known as toring for the floor. In every Bidayuh village, there is an octagonal community house known as Baruk, a place where the people practised their rituals and customs and socialised during festivities (Ungang, 2006) as well as a place where the skulls of the fallen enemies where kept, mostly placed in a wooden trunk and only brought out during Gawai festival for their cleansing rituals.

The traditional Bidayuh's belief system mainly focused on their ancient tradition or adat oma and spiritual beings which are connected to nature. They believed that everything in nature has spirits. Several observations and findings revealed that within the Bidayuh's traditional religion, there might have been Hindu influences at the time the Majapahit Empire spread throughout Borneo during the $14^{\text {th }}$ century, such as several Bidayuh spirits' names which are similar to the Hindus (Low, 1848), the findings of Hindu figures along the Sarawak river basin and near Sempro below Kampung Benuk/Segu, Penrissen in the 1840s (Chang, 2002) as well as some practices which were similar to Hinduism including the cremations of the dead (Baring-Gould \& Bampflyde, 1909), forbidding beef consumption among the priestess or Dayung Borih (Ling Roth, 1896; Nuek, 2002), and belief in the stars and heaven (Minos, 2000).

The two most important spirits for the Bidayuh were Iyeng podi or the Rice spirit and Iyeng Sumuk Babai, the spirits of the ancestors. The Bidayuh believed that these two spirits influenced and affected their daily lives especially where rice cultivation was concerned.

The Bidayuh believed that it was essential to seek permissions and blessings from these spirits to ensure that life was balanced. Proper offerings would reap positive output in the form of good health, safety and wealth. If the spirits were displeased with the people, then they feared that bad luck would come about as a result, such as diseases, spoilt vegetation and even attacks from both human enemies and wild animals. This was where the adat oma played a role as a guideline in the Bidayuh community. The adat oma guided the people on what to do (Nuek, 2002). These were rules which prohibited acts which may provoke the spirits and the Bidayuh priest and priestess established these adat oma. Both priest and priestess were dominant figures in the Bidayuh community. They ensured that the adat was upheld and respected so as not to provoke the spirits. 
One of the ways in which this was done was through the rituals of Gawai. Gawai, in its traditional context is a very spiritual and complex ritual. It could only be conducted by the priestess, Dayung Borih and priest, Kitua Gawai. However, the Dayung Borih played a more dominant role in the Gawai.

Within the Bidayuh community, women play an important role, especially in relation to the Bidayuh traditional customs or adat oma. These women, or priestess, are known as Dayung Borih in the Bau-Jagoi group. These women are highly respected women who were 'chosen' by the spirits to perform the rituals of adat oma. They are also skilled in singing the Borih, ritual songs which are sung during the Bidayuh festival of Gawai (Nuek, 2002). These ritual songs are said to transport the spirits of the Dayung Borih to the spiritual world where they meet with the spirits of the ancestors as well as their spiritual husbands. According to Nuek (2002), the Dayung Borih would learn these songs, which contained language which is difficult for ordinary people to understand, at a very young age, as early as three to four years old.

The main role of the Dayung Borih is to carry out the traditional Bidayuh customs, adat oma, especially during Gawai. They ensure that the Gawai is performed correctly as to please the spirits, thus ensuring good harvest and blessing for the village for the new rice planting cycle. Some Dayung Borih are also gifted in different areas including midwifery, healing in terms of physical and spiritual or even interpreting dreams and casting away evil spirits.

This paper discusses the role and significance of the Bidayuh priestess or Dayung Borih in the Bidayuh community with reference to Gawai. Gawai is a very important celebration among the Bidayuh, however, due to modernisation, the true meaning and significance of the Gawai is lost. The Dayung Borih now plays a secondary role in the Gawai celebration, whereby in the olden days, they were the primary people responsible for conducting and participant in these Gawai rituals. This paper also dwells into the concept of Gawai in its traditional sense. With the coming of new religion such as Christianity, the role and significance of Dayung Borih, as well as Gawai in its true sense, has been lost. Therefore, in order to sustain the cultural heritage and identity of the Bidayuh people, it is important to understand the role of Dayung Borih together with the concept of Gawai.

\section{Literature Review}

The role of women in most cultures have often been overlooked and ignored. Studies in most Asian cultures however suggest that women play a very prominent role in certain cultural communities, if not more dominant than men. 
This could be because women were thought to have a more 'soft soul' which were reachable by the spirits (Hussin, John Baptist \& Pugh-Kitingan, 2018).

The roles that these women took were often in the form of healers or spiritual mediators, people who are closely connected to the spiritual world. They could also be associated to shamans, mana or spirit medium. Shaman is a term used to refer to those who are able to heal and protect others through spirits using rituals (Hussin, 2003). Arenawati (1978) relates this definition of shaman with the Kadazan priestess known as Bobohizan, ladies who are both healers and protectors. Shamans and Bobohizans are highly respected in their communities and are believed to have special abilities and power. Bobohizan are also compared to spirit mediums, who are regarded as mediators between human and the spiritual world (Hussin, 2003).

The Bobohizan of the Kadazan community in Sabah, Malaysia, is an example of the significant role that women play in a particular cultural community. They are regarded as experts in reciting sacred chants which are important for their rituals (Hussin, 2003). Bobohizans are both priestess and healers who are also mediators, connecting the Kadazan people with the spiritual world. They ensure that both the physical and spiritual worlds are balanced and therefore creates harmony among the people.

The Dusun Lotud's traditional religion also have women who are regarded as priestess and their roles are more dominant than men (Deejay, 2016). For the Bobohizan of Kadazan, they carry the roles of priestess and healers; however, the women of Dusun Lotud have three different roles, which are tantagas, libabow as well as minor roles (Deejay, 2016).

A tantagas functions as a priestess and is fully dominant in the role, which is to balance the physical and spiritual worlds through the chants of their rituals (Deejay, 2016). A libabow, on the other hand, are spirit mediums and healers who could communicate with spirits from the other realm. They usually play a secondary role in certain ceremonies and often helps the tantagas. Women also have minor roles in which they are less dominant such as performing ritual dances and music.

These women have to undergo specialised training which is complicated and complex for it requires mental and spiritual strengths. In fact, Hussin (2003) stated that for the training of the Bobohizan, it might take up to seven years consisting of nine levels. They are required to memorise the sacred chants and rituals which contains ancient words and rites. In most instances, these women were 'called' or chosen to be priestess, believed to be by the spirits, thus makes them special. 
The responsibilities carried by these women are heavy because the wellbeing of the village, especially the spiritual well-being, falls within their hands. As mentioned before, they are responsible for ensuring the balance between the physical and spiritual worlds and this is done through sacred rituals and rites. Most of these rituals are very demanding and require full participation and concentration from these women (Hussin, 2003). When these women perform their rituals and connect with the spirits, they are often in a state of trance (Hussin, 2003). This itself is physically demanding. Therefore, even though their position in society is highly respected and looked upon, the responsibilities that they carry are physically, mentally and spiritually challenging.

The theoretical framework in which this study is based on is Toelken's (1996) Cultural Worldview. According to Toelken (1996), Cultural Worldview is the way members of a community sees and comprehend the world around them and is based on their belief systems, cultural values and norms. It reflects the community's culture and beliefs. Toelken (1996) also stated that different cultural communities would have their unique ways of looking at and understanding the world and these are reflected in the culture and cultural activities.

\section{Methodology}

The data for this paper was derived from fieldworks conducted between 2018 to 2019 in two villages in the Bau district, which are Kampung Duyoh and Kampung Sarasot. The data was obtained through two main methods which were observation and interview. During the research period, participant observation was done in Kampung Sarasot to observe the traditional Gawai. Besides that, literature from previous studies was also used for this paper, especially the ones related to the Bidayuh group of Singai.

Interviews were later conducted with the Dayung Borih in both Kampung Sarasot and Kampung Duyoh. Due to shortage of Dayung Borih, most villages in the Bau district often use Dayung Borih from other villages if they wanted to conduct the traditional Gawai. The interviews with the Dayung Borih was done to gain more insight into the cultural knowledge related to both Gawai and Dayung Borih rituals from the perspectives of the Dayung Borih.

\section{Results and Discussion}

\section{The Gawai ritual of the Bidayuh}

The Bidayuh of Sarawak celebrates a yearly celebration known as Gawai. The term Gawai is commonly defined as 'celebration' (Dayak Bidayuh National Association, 2013) or "harvest festival' (Nissom, 2013). Patrick Rigep Nuek (2002) defined 
Gawai as 'a combination of festivals, rituals and ceremonies throughout the farming year, centred around the production of podi [rice]" (p. 272). Basically, what comes to mind when the word Gawai is mentioned is that it is a form of the festival for the Bidayuh. The concept of Gawai however goes further than that definition. Based on the observations and interviews conducted, Gawai in its traditional form could be regarded as a combination of rituals and celebration deeply connected to the spirits. It could also be seen as a concept of communicating with the spirits.

As mentioned previously, the traditional Bidayuh believed in the existence of spirits, or Iyeng, which influences their daily lives. Two of the most common spirits were Iyeng Sumuk Babai or spirits of the ancestors and Iyeng Podi or spirit of the rice. Since the Bidayuh were mainly farmers in the olden days, they believed that Iyeng Podi helped in the production of rice supply. As for Iyeng Sumuk Babai, they were believed to watch over and protect the people of the village, and their presence were therefore also important in the Bidayuh belief system.

According to a Bidayuh myth, the Bidayuh customs related to rice are believed to have been taught by two spiritual beings named Ngoma and Saya (Nuek, 2002). In this myth, a young lady by the name of Ronai was impregnated by a spiritual being, named Ngoma, said to be one of the constellations of eight stars. Ronai gave birth to a boy whom she named Gonuot. As a young man, Gonuot decided to look for his father Ngoma in the sky, rongit. On his journey, Gonuot was assisted by a group of eight stars, one of which he married named Saya. Gonuot finally reached to his father and stayed with him in the sky. However, one day, Gonuot saw his mother crying and missing him, so both the father and son decided to descend to earth and Ngoma became a mortal. It is said that Ngoma who became a mortal, have taught the Bidayuh the borih songs which were sung by the Dayung Borih or priestess during Gawai. The story continues when one day Gonuot who was dibbling holes in the ground to plant rice seeds. He was however shocked to find the seeds were already planted by someone else, despite the fact he could not see anyone nearby. When he told his father of what had happened, his father advised him to take dewdrops in the morning and wipe them on his face and to recite some verses his father taught him. He saw his star wife, Saya appeared. Saya told Gonuot that she came down to earth to help him by planting rice. The Bidayuh believed that Saya taught them different Gawai related to rice and rice planting. Patrick Rigep Nuek (2002) revealed that in order to remember these two deities, a short poem was often recited by the Bidayuh (see Table 2). 
Table 2: The short poem recited to remember Saya and Gonuot

\begin{tabular}{|l|l}
\hline Seduma ribuo rois & Like a cold wind in the orchard \\
Porang nobong prasu tupia & Where there are many squirrels \\
Ngoma toban adat Boris & Ngoma revealed adat Boris \\
Saya toban adat Gawia & Saya revealed adat Gawia. \\
\hline
\end{tabular}

Source: Patrick Rigep Nuek (2002, p. 141).

Since the Bidayuh depended much on rice planting, these two adat - Gawai and Borih - were considered as very important to ensure that they have enough supply of rice for the family for the year.

Based on Nuek's (2002) study on the Bidayuh of the Singai group, there are seven types of Gawai which centres around podi. Each Gawai was held before any form of activity was done to ask permission and blessings from Iyeng Podi. The seven Gawai of the Singai group related to podi are:

Table 3: The seven Gawai related to podi

\begin{tabular}{|l|l|}
\hline Gawai Ayuh Obuo Sowa & Held after harvesting activity \\
\hline Gawai Juran Tubi Bauh & $\begin{array}{l}\text { Held before the harvesting activity - to bless the new rice. } \\
\text { After this Gawai is held, only then the Bidayuh started } \\
\text { harvesting. }\end{array}$ \\
\hline Gawai Maan Kuduos & $\begin{array}{l}\text { Held before eating a new crop of vegetables (in between the } \\
\text { planting and harvesting of podi) }\end{array}$ \\
\hline Gawai Ngirangan & Held to prevent pest or evil spirit attacks on the podi. \\
\hline Gawai Papau & Held after clearing of the land for farming. \\
\hline Gawai Poris Oran & Held before the clearing of the land for farming. \\
\hline Gawai Tugar & Held before burning the cleared plots of land for farming. \\
\hline
\end{tabular}

Source: Patrick Rigep Nuek (2002).

The Bidayuh in the Jagoi group also has several Gawai celebrations related to rice or podi planting. Based on the interviews conducted, these are as shown in Table 4.

Table 4: The different Gawai of the Jagoi group.

\begin{tabular}{|l|l|}
\hline Gawai Tadkong & Done after harvesting of rice \\
\hline $\begin{array}{l}\text { Gawai Siyang } \\
\text { Ratus }\end{array}$ & $\begin{array}{l}\text { Give payment of the land that we use, the patch of land that } \\
\text { we grow our fruit trees to them (land spirit) - give money to } \\
\text { pay for the rent. } \\
\text { Give rice grains to give to the land soul and abstinence for } 2 \\
\text { days. }\end{array}$ \\
\hline
\end{tabular}




\begin{tabular}{|l|l|}
\hline Gawai Oran & $\begin{array}{l}\text { Before planting rice, they need to do ngawah, which is to burn } \\
\text { a small plot of land. If there is no sound during the burning } \\
\text { time, rice can be planted at the land. }\end{array}$ \\
\hline Gawai touk & $\begin{array}{l}\text { If there is sound, then have to do, require sacrificial chicken } \\
\text { or pig. }\end{array}$ \\
\hline Gawai sauh & After burning the field. \\
\hline Gawai Bangas & Performed when insects or rotten roots attack rice. \\
\hline Gawai nuboh & Remove bad souls. \\
\hline
\end{tabular}

Most of these Gawai are conducted for one day. It is vital that after a Gawai is conducted, a period of abstinence or porih is observed. Usually, the abstinence period is for two days. Within the abstinence period, the villagers are forbidden to go to the forest to work such as farming, hunting or even collect firewood. They must also not pound rice and carry baskets used for farming, juwah. Anything related to working is strictly forbidden. Besides that, they must also observe silence within their houses and doors are closed for that period of porih.

The main reasons the Gawai is conducted is to remove and chase away bad luck, and evil spirits whom the Bidayuh believed could 'ride' on them and live with them uninvited. These spirits would gobble and eat up their food, thus making the supply lesser and lesser. If these spirits touched the food, then the food would either be bad and rotten or used up quickly. According to the informant, during Gawai Tadkong, a thorny plant which is mostly found in the forest, known as Bikarom is hung near the main door of the house. They believe that if a spirit visits the house and see the bikarom, it would be afraid and go away.

\section{Figure 2: Bikarom}

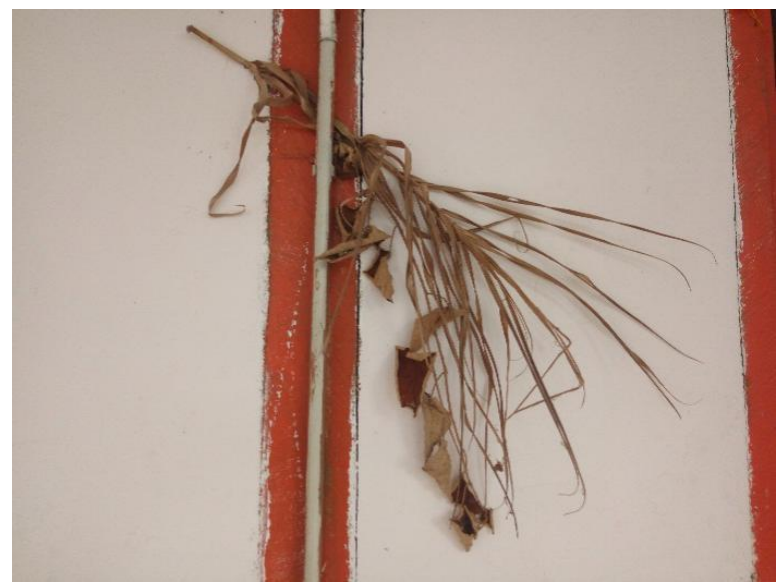

(Source: Yvonne Michelle Campbell, fieldwork, 2018.) 
The yearly Gawai or Gawai Ayuh Obuo Sowa is considered the largest Gawai and is commonly waited for. It is done after all harvesting has been done as a form of thanking Iyeng podi and asking for a good year the following year. Not only does it focus on the rice or podi planting, it also focuses on the harmony, safety and health of the people in the village in general. The main people who are involved in this Gawai are the Dayung Borih, Pak Nyigar or Priest. This Gawai is usually conducted for three days and four nights.

\section{Being a Dayung Borih}

Gawai and Dayung Borih are deeply connected to one another. One could not exist without the other. In the traditional Bidayuh of Bau's beliefs, both Gawai and Dayung Borih play significant roles in their daily lives.

According to the informant from Kampung Duyoh, Madam Mimah anak Nyoib, it is believed that once upon a time, there was a ghost, Gambut Sikubun who fell in love with a Bidayuh girl. Because of that, the girl fell gravely sick and became unconscious. Because she has been in such an unconscious state for so long, the villagers thought that she was dead and as in the customs of the traditional Bidayuh, she was to be burnt. However, Gambut Sikubun felt pity towards her and carried the unconscious woman whose people have not burnt her body back to the sky. This healed her, and she woke up with special abilities to communicate with the spirits and heal people.

The Bidayuh people believed that when women who fell gravely ill and at times unconscious, they were made sick from physical contact or after dreaming about and contacted by spiritual entities, especially Iyeng podi. This is considered as the first sign that the woman can only be healed through Borih treatment. In order to heal herself, she must consent to participate in Gawai Sibarih and accept the role of Dayung Borih. In some instances, these women were selected when they were still very young. Madam Sinan anak Nyuih, a former Dayung Borih from Singai, stated that she fell very ill when she was only two years old. The healers told her parents that she was chosen to be a Dayung Borih and only when they agreed to give her to a Sindo' Borih or a Dayung Borih trainer, would she be healed.

After years of training, the Dayung Borih is ready to be conferred the title and status of a Dayung Borih. During this time, the Gawai Sibarih is performed. She is then a Dayung Borih for the rest of her life and has to participate in Gawai rituals as part of her calling.

Based on the story of the girl who was sick, the Bidayuh believed that when a woman became a Dayung Borih, she is married to the Sikubun soul and this would help cure the sickness and restore her health. Madam Sinan and Madam Mimah informed that each Dayung Borih has their spirit husband who resides in 
Mount Santubong even though they are already married to a human here on earth. According to them, their spirit husbands would often communicate with them to teach, warn or even instruct them on matters related to the spiritual world.

One of the crucial things that a Dayung Borih must learn is the ritual songs known as Borih, which is believed to be taught by the deity, Ngoma (Nuek, 2002). These songs contain ancient languages which could not be understood by ordinary people, and even the Dayung Borih may not know these words (Nuek, 2002). The informant of the interview stated that it is hard for the Dayung Borih themselves to identify the words of these Borih because they come from a very ancient root. When asked to recite these songs, they could not do it unless it was a Gawai and they were already prepared. Nuek (2002) also stated that there are different categories of Boris such as Boris Mudiek, Boris Birayar, Boris Mori, Boris Sinak, Boris Mamuh, Boris Ngidaan Rasang, Boris Pinya and Boris Butan. Each of these songs serves different purposes and used for different occasions and situations.

Gawai Kibaris Dayung or Gawai Sibarih takes place when a lady is conferred the tile of Dayung Borih. During this time, the newly conferred Dayung Borih would be presented with a rasang, a symbol of Dayung Borih. The rasang, which is believed to help the Dayung Borih fluent in her borih would be hung in the attic of her house (Nuek, 2002). According to Patrick Rigep Nuek (2002) a rasang is

A wooden plank more than a metre long from one end to the other, and slightly less than half as wide. All along the lower part were holes, through which were hung young, long, still unopened strips of rasang leaves, which were about a metre long. (p. 138)

The rasang, which is taken down during Gawai Ayuh Obuo Sowa would be kept in the attic for the Dayung Borih's lifetime. The Bidayuh consider rasang a sacred thing and therefore should not be touched by anyone other than the Dayung Borih.

During this Gawai, all the Dayung Borihs who are invited would encircle the newly made rasang eight times while singing the Borih Ngidaan Rasang.

\section{Dayung Borih and Gawai}

The Dayung Borih plays a very important role in the Bidayuh Gawai, especially the Gawai Sowa or Gawai Ayuh Obuo Sowa. According to Madam Mimah anak Nyoib, there are three groups of people who participate in the Gawai and they are Dayung Borih, Pak Nyigar and Pak Ngaduop. Having the special gift of connecting with the spiritual world, the Dayung Borih's roles are crucial in ensuring that the spirits are summoned adequately for their blessings and permission. As mentioned in the 
previous section, Dayung Borih are experts in singing the sacred songs of Borih which are used to communicate with the spirits especially with the spirits of the ancestors, Iyeng Sumuk Babai and spirit of the rice, Iyeng Podi. This form of communication refers to the Dayung Borihs' ability to travel to and from the spiritual world to meet up with these spirits, to give thanks for the harvest of the year as well as to ask for blessing and permission to start the new rice planting season. This is to ensure that the village would gain better harvest the following year and to avoid any form of bad luck which might fall upon the village.

During Gawai, the Dayung Borih would sing their Borih songs while sitting on a wooden plank hung from the ceiling of the Gawai house or Bori Gawai. These songs are long and may take several nights to finish, usually four nights; therefore, the Dayung Borih would take a turn in singing these songs. On the fourth and final night, the Dayung Borih would dance around the offering hut or Bawar in the form of moving from left to right and continuing with the Borih songs. A bawar is important in Gawai because it is the offering hut where offerings for the spirits of the ancestors and rice spirit are placed. This is crucial because the Bidayuh believed that when they call upon the spirits to come and visit them, they need to prepare food as the offering. The offerings would usually consist of romang (glutinous rice cooked in coconut milk, wrapped in leaves and cooked in bamboo), sukuoi (rice wrapped in leaves and cooked in bamboo containing water), pogang (glutinous rice cooked in bamboo) chicken, tuak (rice wine) and pig. It is hoped that the spirits would be pleased with these offerings and therefore bless the people. On the final night, it is the turn of the Dayung Borih to visit the ancestors in the spiritual world.

One by one, they would climb a ladder built near the hut, known as simutur. At the same time, they would continue dancing and as they started to reach the climax of their songs, they would jump up and down, which is part of their trance. When they have finally reached the climax of their song, they would collapse and faint but standing by would be some of the men, ready to catch them. The Bidayuh believed that when these Dayung Borih faint, their souls have reached the spiritual world. To wake them up, the Kitua Gawai or head of the Gawai, would whisper some chants in their ear and this would wake the ladies up from their faint.

For a complete and successful Gawai, there is some equipment which is important and part of the Gawai ritual. One of them is a red plant, known as Bunga' is put beside the ladder, simutur because it is believed that this plant has the ability to bring the spirits of the Dayung Borih up to the spiritual world. The Bunga' plant is considered as a sacred plant by the Bidayuh because it was believed to have 
been a gift from the spirits. It could be regarded as a form of transportation to transport the Dayung Borihs' spirits up to the spiritual world.

Another item which is important in the Gawai ritual is Taya. According to Nuek (2002):

Taya is eight roughly woven pieces of split bamboo forming a square about $20 \mathrm{~cm}$ square, tied to a tajur using string made from the inside of the bamboo used to cook purut rice; the tajur, in turn, is pierced through the roof of the akat.

The Taya is then hung on the ceiling of the offering place, bawar during Gawai. As the Bunga' is regarded as a transport to carry the spirit of the Dayung Borih up to the spiritual world, the Taya is a tool which is believed to bring back home the spirits.

Another way in which the Dayung Borih communicates with the spirit, especially the rice spirit, Iyeng Podi, is through a ritual which is also a must in Gawai Sowa is through the ritual of Ngirara. Here, the Dayung Borih would wave an empty triangular basket known as sukuop in a nearby stream while chanting the Borih. After a while, one would find some grains of unhusked rice or podi in the basket. This is regarded as a connection with Iyeng podi.

Besides that, during the Gawai itself, while at the Gawai house, the Dayung Borih would sing their Borih songs. According to Nuek (2002), ten Borih songs are sung throughout the night until the dawn during the Gawai Ayuh Obuo Sowa. These songs tell the journey of the Dayung Borih's spirit to the spiritual world to meet with Iyeng Sumuk Babai. They also believed that during this time, their spirit would travel to Mount Santubong, which they consider as a sacred place to meet their spirit husbands. During this singing of the Borih, the Dayung Borih would swing on a wooden plant which is hung from the ceiling of the Gawai house.

\section{Gawai for healing}

The Dayung Borih are not only responsible for conducting Gawai related to podi planting, but they are also regarded as shaman because of their healing capabilities. Since Dayung Borih could communicate with the spirits, they have the capabilities to reach out to the spirits in situations where a human spirit is 'disturbed' by these spirits. In order to communicate with these spirits, healing Gawai needs to be conducted. From interviews conducted, four types of healing Gawai is performed by the Dayung Borih.

The first one which is meant for normal ailments such as fever and bruises on the body is known as Gawai Kijarat. For this particular type of healing Gawai, 
only one Dayung Borih is required to heal the patient. The only need for this particular healing Gawai is that the patient must stay indoor for one day after the ritual.

The second one is Gawai Mongi. Mongi for babies is done when a baby cries non-stop for weeks or even months and are believed to be disturbed by spirits, whereas Mongi for adults are usually done after the Gawai Kijarat treatment has shown no desirable effect. For this type of healing, two Dayung Borihs are required to heal the patient, and after the healing, the patient must stay indoors for two days and they must not touch fire.

Gawai Ngirabou is the third type of healing Gawai which is often conducted if the Gawai Mongi is not effective. This is a more complicated form of healing ritual whereby it must be performed starting from night time to dawn. In this ritual, usually a dog is sacrificed to banish evil spirits whereby the dog's blood is to be rubbed on the weak spot. After the ritual, the patient must stay indoors for three days.

The last and most complex healing Gawai is Gawai Pinya'. This is usually done after all the other healing Gawai has been carried out but the patient is still not healed or unwell, usually involving extreme ailments. For this particular healing Gawai, the Dayung Borih would recite their sacred chants every day to help heal the patient. After this particular ritual, the patient must stay indoors for eight days.

\section{Conclusion}

This paper examines the role and significance of Gawai and Dayung Borih within the Bidayuh community. Traditionally, the concept of Gawai could be seen as a form of rituals which relates human to spiritual beings. It could also be seen as a form of communication between human and spiritual beings. This is where the Dayung Borih comes in. They act as mediators to connect the Bidayuh people and the spiritual world, something which they strongly believed in the olden days and dramatically influences their lives.

Gawai is not only related to podi and podi planting but they are also Gawai which are conducted for healing purposes, especially where spirituality is concerned. Here, the Dayung Borih again plays a vital role as not only mediators but also healers.

These few chosen women who are specially selected by the spirits are very important people for the Bidayuh community. Without them, there would be no balance and mediator between the human world and the spiritual world. They 
are considered special as they could communicate with the spirits and have the gift of healing.

In today's society, Gawai is now seen as just another form of tribal celebration for the younger generations. Since most Bidayuh has converted into Christianity, most of the traditional ways or adat oma has been forgotten. There are efforts to revive and preserve the traditional Gawai by various Bidayuh bodies or associations like the Dayak Bidayuh National Association (DBNA) and the Jagoi Heritage but it is also an alarming fact as the numbers of Dayung Borih is dwindling over the decades, so too will the unique Bidayuh Gawai tradition and ancient rituals. As said by one of the informants, one of the last remaining Dayung Borih:

Nouh nya'a so'on ndi sidoh. Piobuo' sowa' ke so'on podi de bogok. Adin nya'a bigawea, kan rasuk oggi' duit de so'on eh watki. Nya'a ndai okes, ndai kede, rasuk jading duit...Okan wat so'on. Noh ngan nya'a adin bigawea sowa kan nya'a raan. Pak eh adin tiya' doi' tiya' nya'a de ya bigawea. Urang moh obuo. Nak oggi' nya'a de raan. Suo' nya'a obuo' dorie'. Pak eh rami...nya'a moh buon adat noh, moh ya' odi ke adat okon tiya'. Pak kadak koih de aruo' oggi' tih na'an ja'. Mana-mana wat eh, kan mo doi' manah nya'a duwoh nyak nai. Moh ro'o ojuog-ojuog nyek....Nog ngan eh, adin nya'a dorie' ya' ndai oni de susah watnoh eh. Jok ra'an de doi' patang eh. Susah bih nyam eh. Mo doi' wat eh, dop odop nyak kan mo da'ang tih.

[In the past, people may celebrate it once a year. In the end of the next year, they will get bountiful harvest as a result. However, Gawai nowadays is a means to earn instant money. People set up bands of singers, set up shops and get instant money...It was for a different cause. Now people celebrate Gawai if they wished to. But without the rituals. The Gawai people are diminishing. No one wants to be Gawai people. All of them did not want it. But the Gawai sowa now are festival like...They were fed up with Gawai tradition and move on to other religion, but those like me who still believe in Gawai just hold on. Whatever there is no other believer to use the tradition together, I stand alone by myself now.... That is why nowadays, people refuse to do all these hard traditions. They want to have an abstainfree tradition. As for me, I have no choice as I am a Gawai believer.]

The purpose of modern Gawai has shifted from asking permission and blessings from the spirits of the ancestors and rice to one which involves celebration and indirectly to give thanks to God for a good year, which may not necessarily be based on podi planting since the younger generation of Bidayuh 
nowadays are no longer farmers. So too the role and significance of the Dayung Borih within the modern Bidayuh community.

\section{Acknowledgements}

The authors would like to thank and acknowledge the financial support provided by the Institute of Borneo Studies, Universiti Malaysia Sarawak under the Dayak Chair Foundation for the research grant F09/DRC/1641/2018. The authors also acknowledge the contributions made by the research participants, namely the Dayung Borih of Kampung Singai, Kampung Duyoh and Kampung Sarasot in Bau who patiently took part in this study. This study would not be possible without all of their assistance.

\section{References}

Arenawati. (1978). Peribumi Sabah: Satu tinjauan dalam konteks kepercayaan, kultus dan hukum adat di Sabah. Kota Kinabalu: Yayasan Kota Kinabalu.

Baring-Gould, S., \& Bampfylde, C. A. (1909). A history of Sarawak under its two White Rajahs, 1839-1908. London: Henry Sotheran \& Co.

Bongarra, M., Kayad, F. G., \& Campbell, Y. M. (2017). The Bidayuh-languages or dialects? In M. Bongarra, M. Arritt, \& F. G. Kayad (Eds.), Selected papers of the Bidayuh language development and preservation project (2003-2017) (pp. 207220). Kuching, Malaysia: Dayak Bidayuh National Association.

Chang, P. F. (2002). History of Bidayuh in Kuching division, Sarawak. Kuching: Sarawak Press Sdn. Bhd.

Chang, P. F. (2004). History of Serian Bidayuh in Samarahan division, Sarawak. Kuching: Sarawak Press Sdn. Bhd.

Dayak Bidayuh National Association. (2013). Buk baang sinda: Bidayuh Bau-Jagoi wordlist. Kuching: Dayak Bidayuh National Association.

Deejay, D. A. A. (2016, 16-17 November). A review on the role of women in the traditional religion of the Dusun Lotud in Tuaran, Sabah. Paper presented at $3^{\text {rd }}$ Kanita Postgraduate International Conference on Gender Studies, Universiti Sains Malaysia (USM), Penang, Malaysia.

Hussin, H. (2003). Bobohizan dan peranannya di kalangan masyarakat Kadazan daerah Penampang, Sabah. JATI-Journal of Southeast Asian Studies, 8, 15-40.

Hussin, H., John Baptist, J., \& Pugh-Kitingan, J. (2018). Enriching the soundscape and dancescape of Sabah through Sumazau. JATI-Journal of Southeast Asian Studies, 23(2), 181-204 
Ling Roth, H. (1896). The natives of Sarawak and British North Borneo, Vol. II. London: Truslove \& Hanson.

Low, H. (1848). Sarawak: Its inhabitants and production. London, England: New Bentley.

Minos, P. (2000). The future of Dayak Bidayuhs in Malaysia. Kuching: Lynch Media.

Nissom, M. P. (2013). Dayak Bidayuh dictionary: Bau/Jagoi/Singai - Bidayuh to English, English to Bidayuh. Kuching: Perpustakaan Negara Malaysia.

Noeb, J. \& Ridu, R. S. (2017). Language development in Bidayuh: Past, present and future. In M. Bongarra, M. Arritt, \& F. G. Kayad (Eds.), Selected papers of the Bidayuh language development and preservation project (2003-2017). Kuching: Dayak Bidayuh National Association.

Nuek, P. R. (2002). A Dayak Bidayuh community rituals, ceremonies and festivals. Kuching: Lee Miing Pres Sdn. Bhd.

Toelken, B. (1996). Cultural worldview. In B. Toelken (Ed.), Dynamics of folklore. Logan, Utah: Utah State University Press.

Ungang, C. (2006). Baruk: Sebuah institusi sosial dan budaya masyarakat Bidayuh. Master's dissertation, Faculty of Applied \& Creative Arts, University Malaysia Sarawak, Kota Samarahan, Malaysia.

Date Received: 16 August 2019 Date of Accepted: 15 November 2019 